\title{
Phytoremediation Potential of Vetiver Grass (Vetiveria Zizanioides) in Two Mixed Heavy Metal Contaminated Soils from the Zoundweogo and Boulkiemde Regions of Burkina Faso (West Africa)
}

\author{
Norbert Ondo Zue Abaga ${ }^{1 *}$, Sylvie Dousset ${ }^{2}$, Colette Munier-Lamy ${ }^{2}$ \\ ${ }^{1}$ Université des Sciences et Techniques de Masuku (USTM), Unité de Recherche en Sciences de la Terre et de l'Environnement \\ (URESTE), Franceville, Gabon \\ ${ }^{2}$ Université de Lorraine, CNRS, Laboratoire Interdisciplinaire des Environnements Continentaux (LIEC), Vandoeuvre-lès-Nancy, \\ France \\ Email: ${ }^{\star}$ _ondo@hotmail.fr
}

How to cite this paper: Ondo Zue Abaga, N., Dousset, S., \& Munier-Lamy, C. (2021). Phytoremediation Potential of Vetiver Grass (Vetiveria Zizanioides) in Two Mixed Heavy Metal Contaminated Soils from the Zoundweogo and Boulkiemde Regions of Burkina Faso (West Africa). Journal of Geoscience and Environment Protection, 9, 73-88. https://doi.org/10.4236/gep.2021.911006

Received: May 28, 2021

Accepted: November 20, 2021

Published: November 23, 2021

Copyright ( 2021 by author(s) and Scientific Research Publishing Inc. This work is licensed under the Creative Commons Attribution International License (CC BY 4.0).

http://creativecommons.org/licenses/by/4.0/ (c) (i) Open Access

\begin{abstract}
In the agricultural regions of Burkina Faso, urban solid waste fertilizers were usually applied. This activity is likely to contaminate the soils and expose populations to serious diseases. This study aims to assess rate of heavy metal $(\mathrm{Cd}, \mathrm{Cu}, \mathrm{Mn}, \mathrm{Pb}, \mathrm{Zn}, \mathrm{Ni}, \mathrm{Cr})$ contamination in both agricultural lixisol and vertisol and to evaluate the removal efficiency of heavy metals using Vetiver grass on different two mixed heavy metal contaminated soils. A pot experiment was conducted to compare the metal accumulation and overall efficiency of metal uptake by different plant parts (roots and shoots) on both tropical soils. After 3 and 6 months growing on laboratory conditions, Vetiver grass plants were harvested and heavy metal concentrations in shoot and root parts determined by Inductively Coupled Plasma - Atomic Emission Spectroscopy. The results indicate that at 3 and 6 moths, the shoot and root concentrations of heavy metals in Vetiver grass harvested in lixisol were higher than vertisol. For different plant parts, all metal concentrations were higher in root than in shoot, except $\mathrm{Cu}$ and $\mathrm{Pb}$. At the 3 and 6 months, the $\mathrm{BCF}$ values $>1$ for $\mathrm{Cd}, \mathrm{Cu}$ and $\mathrm{Zn}$ in both soils showed Vetiver grass as an effective phyto-stabilizer for these metals. However, the TF values $>1$ for $\mathrm{Cd}$ (lixisol), $\mathrm{Mn}, \mathrm{Zn} \mathrm{Ni}$ and $\mathrm{Cr}$ (vertisol) indicated the efficiency of Vetiver for phytoextraction. The results of this study showed that Vetiver is more effective in lixisol, but it can be used for remediation of both studied tropical soils from agricultural region of Burkina Faso. Nevertheless, considering the spe-
\end{abstract}


cial limitations of the experimental conditions, further field monitoring is necessary to demonstrate the phytoremediation efficiency of Vetiver in agricultural soils under the climatic conditions of Burkina Faso.

\section{Keywords}

Vetiver Grass, Heavy Metals, Lixisol, Vertisol, Phytoextraction, Phytostabilization, Contamination

\section{Introduction}

Over these last years, soil contamination has received much global attention as it instigates considerable risks to both human health and the environment (Doran, 2002; Azam, 2016; Gómez-Sagasti et al., 2016). Anthropogenic sources of soil contamination may include both organic (pesticides, dioxin, poly-chlorinated biphenyl, halogen) and inorganic (metals and radioactive materials) components (Storelli, 2008; Ali \& Khan, 2017). The major components of inorganic pollutants are heavy metals and metalloids, such as chromium $(\mathrm{Cr})$, manganese $(\mathrm{Mn})$, nickel $(\mathrm{Ni})$, copper $(\mathrm{Cu})$, zinc $(\mathrm{Zn})$, cadmium $(\mathrm{Cd})$, lead $(\mathrm{Pb})$, mercury $(\mathrm{Hg})$ and arsenic (As) (Barakat, 2011; Khan et al., 2011). Generally, the term heavy metal is widely used to indicate a group of natural metals in the periodic table with an elemental density $>5 \mathrm{~g} / \mathrm{cm}^{3}$ and atomic number $>20$, often non-biodegradable and persistent in soils over a long duration (Bradl, 2005; Gomes, 2012; Ali \& Khan, 2018). Heavy metals are released into the environment by human activities via industrial and agricultural practices and disposal of urban sewage sludge (Khan, 2005). Some heavy metals, such as $\mathrm{Cu}, \mathrm{Zn}, \mathrm{Fe}$ and $\mathrm{Mn}$, are essential soil micronutrients required by living organisms in trace amounts for biological metabolic processes (Pilbeam \& Barker 2007), and others heavy metals like $\mathrm{Cd}, \mathrm{Pb}$, $\mathrm{Cr}, \mathrm{Hg}$ and As are non-essential for the growth of living organisms. However, all heavy metals are hazardous to human health as it easily bio-accumulated via the food chain due to soil-to-plant transfer of metals (Khan, 2005; Storelli 2008; Martin \& Griswold 2009; Clemens \& Ma, 2016; Ali et al., 2019).

Soil rehabilitation seems necessary in order to avoid human health problems linked to soil pollution. Several physical, chemical and biological assisted methods have been tested to clean up contaminated heavy metals in soils (Garbisu \& Alkorta, 2003; Ghosh \& Singh, 2005; Rahman et al., 2016). However, all of these strategies are expensive, extremely complicated and destructive to the natural ecosystem. Nonetheless, phytoremediation has evolved to be an alternative biological assisted method that is cost-effective, non-destructive and environmentally friendly approach for heavy metals soil decontamination (Glass, 2000; Ali et al., 2013; Mahar et al., 2016). As a consequence, phytoremediation is considered an innovative, economical and environmentally compatible method for heavy metals remediation (Antiochia et al., 2007). Phytoremediation is a technology that transfers pollutants from soils and sediments to the plant tissues 
without soil structure degradation and soil productivity decrease (Lombi et al., 2001). Heavy metal uptake by plants is dependent to soil metal concentration, soil nature and is also affected by plant physiology (Chen et al., 2004).

Somme plant species have great potential to accumulate metals in both shoot and root (Neisi et al., 2014). Vetiver grass, Vetiveria zizanioides (Linn.) Nash is one of the most promising plants due to its fast growing, deep and extensive root system, high tolerance to environmental stress such as extreme fluctuations of temperature $\left(22^{\circ} \mathrm{C}-60^{\circ} \mathrm{C}\right)$, soil $\mathrm{pH}(3.0$ - 10.5), and most importantly high tolerance to heavy metal stress (Danh et al., 2009; Truong \& Danh, 2015; Gnansounou et al., 2017; Darajeh et al., 2019; Ng et al., 2019). Vetiver grass originated in the Indian sub-continent can also be found throughout the tropical and subtropical regions of Africa, Asia, America, Australia, and Mediterranean Europe (Maffei, 2002). Vetiver grass has a very high tolerance for organic and inorganic pollutants and has been used for remediation of soils polluted by pesticides (Ondo Zue Abaga et al., 2014a), phenol, nuclear wastes and protozoa (Singh et al., 2008) and heavy metals (Truong \& Danh, 2015; Suelee et al., 2017; Ng et al., 2020).

Limited data are available about soil remediation especially using Vetiver grass in Africa in general, and particularly in Burkina Faso. Nevertheless, Vetiver grass, Vetiver zizanoides has been studied for stabilization and biodegradation of pesticide in the agricultural cotton-soils of Burkina Fasol (Ondo Zue Abaga et al., 2014a) and for phytoaccumulation of both $\mathrm{Cu}$ and $\mathrm{Cd}$ in agricultural soil (Ondo Zue Abaga et al., 2014b). Therefore, the objectives of this study were to evaluate the accumulation trend and efficiency of metal uptake by Vetiver grass from two mixed form $\mathrm{Cd}, \mathrm{Cu}, \mathrm{Mn}, \mathrm{Pb}, \mathrm{Zn}, \mathrm{Ni}$ and $\mathrm{Cr}$ contaminated soils collected in agricultural region of Brukina Faso. Soil nature influence was investigated on metal bioaccumulation in both root and shoot of Vetiver grass in the laboratory conditions.

\section{Material and Method}

\subsection{Presentation of the Study Area}

Located in the Sudanian and Sudano-sahelian zones of Burkina Faso, more precisely in the provinces of Zoundweogo and Boulkiemde, it contains two (2) experimental sites of cotton zone (Figure 1). They are Kaïbo, between latitude $11^{\circ} 49^{\prime}$ North and longitude $05^{\circ} 56^{\prime}$ West, and Saria between latitude $12^{\circ} 16^{\prime}$ North and longitude $02^{\circ} 09^{\prime}$ West, respectively. The study area is under a dry tropical climate which alternates between a short rainy season and a long dry season. The country has three distinct climatic zones: the Sahel region in the north receiving less than $600 \mathrm{~mm}$ average annual rainfall, the North-Sudanian zone in center with an average annual rainfall between 600 and $900 \mathrm{~mm}$; and the South-Sudanian zone in the south with an average annual rainfall over $900 \mathrm{~mm}$ (UNDP, 2021). Annual average temperatures in Burkina Faso range between $27^{\circ} \mathrm{C}-30^{\circ} \mathrm{C}$, with monthly averages ranging from $14^{\circ} \mathrm{C}-15^{\circ} \mathrm{C}$ (USAID, 2017). The two experimental stations Kaïbo and Saria are characterized by Vertisol and Lixisol 


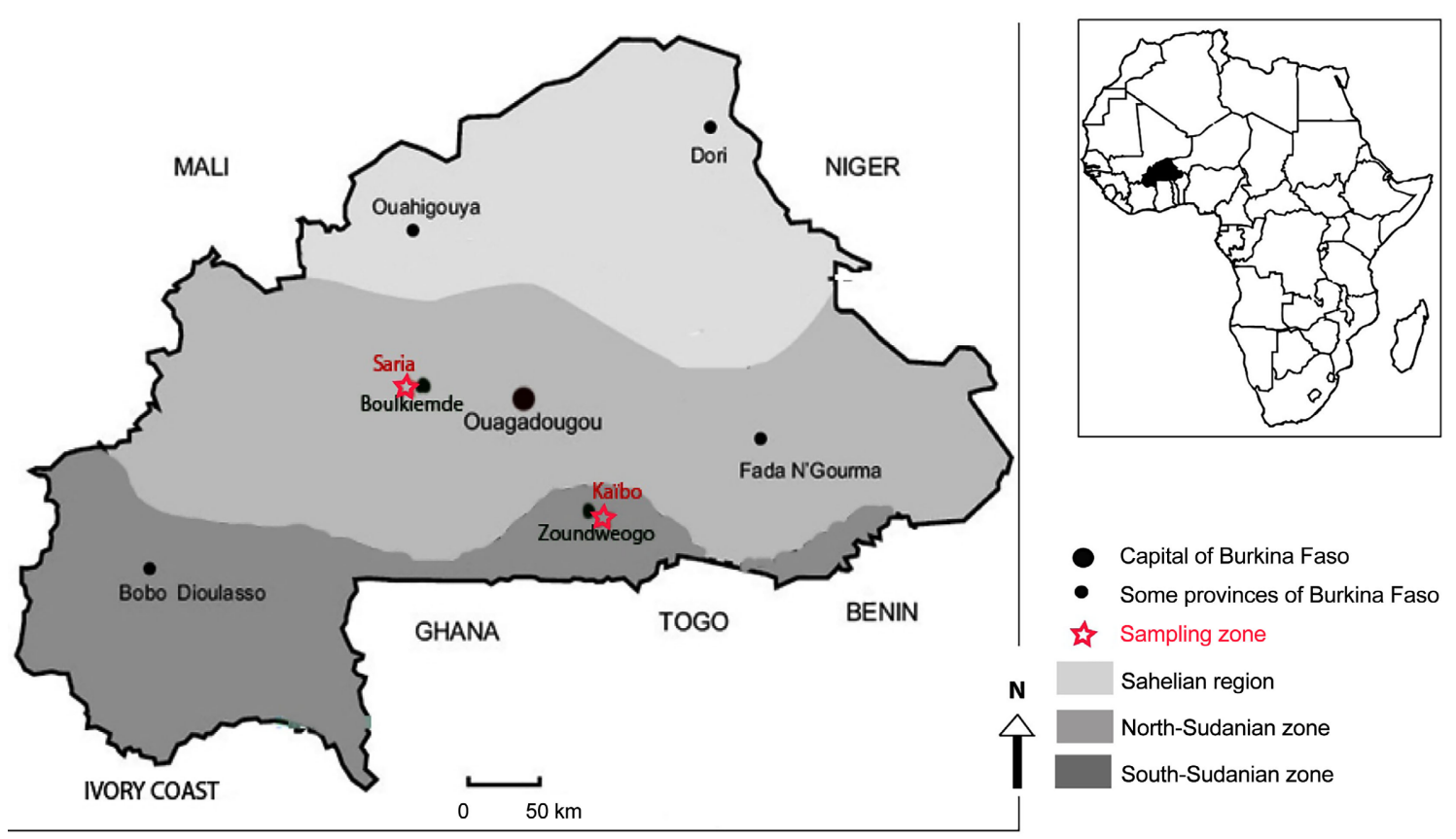

Figure 1. The geographical location of sampling zone in the study area.

(IUSS Working Group WRB, 2006), respectively. The geological formations of the study area are composed of Precambrian rocks generally characterized by granitic gneisses, and north to northeasterly trending belts of metasediments and metavolcanics (Schlüter, 2008).

\subsection{Soil Samples and Physic-Chemical Properties Characterization}

Two experimental soils were taken from the soil surface $(0-20 \mathrm{~cm})$ of two experimental stations, Saria and Kaïbo, in the cotton zone of Burkina Faso (Figure 1). The soil samples were prepared and analyzed as described by Ondo Zue Abaga et al. (2014a). The samples soils were air-dried, sieved to 2-mm, and sent for characterization at the soil analysis laboratory of INRA-Arras in France. The following analyses were carried using the European soils quality standards given in brackets: particle size distribution (NF X 31-107), pH (NF ISO 10390), total organic carbon (NF ISO 10694), N (NF ISO 13878), cation exchange capacity (CEC) (NF X 31-130), and the total major elements (NF X 31-147). A 40-mL volume of the clay fraction $(0-2 \mu \mathrm{m})$ obtained from $6 \mathrm{~g}$ of soil per $500 \mathrm{~mL}$ of water (soil/solution: 1/83.3) was used to determine the mineralogical composition of the clay. Clay mineral characterization was performed using a Broker ${ }^{\mathbb{B}}$ D8 diffractometer (Karlsruhe, Germany), with Co Karadiation. Diffractograms were recorded from $3^{\circ}$ to $40^{\circ} 2 \theta$, with a step scan of $0.035^{\circ} 2 \theta$ and time per step of $3 \mathrm{~s}$ on two preparations: a deposit oriented toward air-dried clays and a deposit oriented toward saturated clays at ambient temperature for $24 \mathrm{~h}$, in ethylene glycol (EG) vapors (Mosser-Ruck \& Cathelineau, 2004).

Total metal (Cd, $\mathrm{Cu}, \mathrm{Mn}, \mathrm{Pb}, \mathrm{Zn}, \mathrm{Ni}, \mathrm{Cr}$ ) concentrations were determined us- 
ing a flame atomic absorption spectrometer (Varian 702-ES). A graphite furnace atomic absorption spectrometer (Varian $220 \mathrm{Z}$ model) was used to measure the $\mathrm{Cd}$ concentrations below $1 \mathrm{mg} / \mathrm{L}$. The limit of quantification was $0.10 \mathrm{mg} / \mathrm{kg}$ dry soil for $\mathrm{Cd}, 1 \mathrm{for} \mathrm{Cu}$ and $4.22 \mathrm{mg} / \mathrm{kg}$ dry soil for $\mathrm{Mn}, \mathrm{Pb}, \mathrm{Zn}, \mathrm{Ni}$ and $\mathrm{Cr}$. In soil, total metal concentrations do not necessarily correspond with metal bioavailable. Bioavailability is the proportion of the total metals that are available for incorporation into biota (bioaccumulation). It is the interest of bioavailable fraction studies of the major metals listed by the Environmental Protection Agency (EPA) of United States (McKinney \& Rogers, 1992). The bioavailable fractions of heavy metals were evaluated using a $\mathrm{MgCl}_{2} 0.1 \mathrm{M}$ extractant (Meers et al., 2007). Heavy metals were extracted from $1 \mathrm{~g}$ of soil mixed with $40 \mathrm{~mL} 0.1 \mathrm{M} \mathrm{MgCl}_{2}$ in a $50-\mathrm{mL}$ polycarbonate vial. The soil suspensions were agitated on a rotary shaker for $1 \mathrm{~h}$ and centrifuged for $10 \mathrm{~min}$ at $2900 \mathrm{~g}$. The supernatant filtered using Whatman filters $(0.45 \mu \mathrm{m}$ pore size) received $4 \mathrm{ml}$ of $69 \%$ nitric acid before the analysis. The heavy metals concentrations were determined by Inductively Coupled Plasma - Atomic Emission Spectroscopy (ICP-AES, Varian 702-ES model) as above with a limit of quantification of $0.25 \mathrm{mg} / \mathrm{kg}$ dry soil.

The soil characteristics are given in Table 1 . The soil texture was loamy clay for vertisol and sandy loam for lixisol according to Jamagne (1967). The organic carbon (OC) content was higher in vertisol $(0.95 \%)$ and the $\mathrm{pH}$ slightly less acidic ( $\mathrm{pH}$ 6.1) than in lixisol (OC $0.43 \%$ and $\mathrm{pH}$ 5.8) (Table 1). Vertisol contained more $\mathrm{Al}_{2} \mathrm{O}_{3}(9.8 \%)$ and $\mathrm{Fe}_{2} \mathrm{O}_{3}(4.6 \%)$ than lixisol $\left(\mathrm{Al}_{2} \mathrm{O}_{3}, 3.5 \% ; \mathrm{Fe}_{2} \mathrm{O}_{3}\right.$, $1.1 \%)$. In the vertisol, clays mineral were more abundant: chlorite (4\%), Illite (45\%), Interstratified Illite/Chlorite (4\%), kaolinite (31.5\%) and smectite + interstratified Illite/smectite (15.5\%) than in lixisol with only Illite (21\%) and a low CEC kaolinite (79\%). These results could explain the most important CEC in vertisol $\left(10.5 \mathrm{cmol} \cdot \mathrm{kg}^{-1}\right)$ compared to lixisol $\left(<1 \mathrm{cmol} \cdot \mathrm{kg}^{-1}\right)$.

The results of heavy metals analyses indicated that total $\mathrm{Cu}, \mathrm{Mn}, \mathrm{Zn}, \mathrm{Ni}$ and $\mathrm{Cr}$ concentrations were significantly $(P<0.05)$ higher in vertisol compared to lixisol (Table 1). For $\mathrm{Cd}$, and $\mathrm{Pb}$, no significant difference was observed between the two soils. However, the total exchangeable metal was similar in both soils for $\mathrm{Cd}, \mathrm{Mn}, \mathrm{Pb}, \mathrm{Zn}, \mathrm{Ni}$ and $\mathrm{Cr}$. Only the extractable-Cu concentration was significantly higher $(P<0.05)$ in lixisol than in vertisol. Finally, the soil content of available trace metals $(\mathrm{Cu}, \mathrm{Mn}, \mathrm{Pb}, \mathrm{Zn}, \mathrm{Ni}, \mathrm{Cr})$ depends on different factors, including the content of organic carbon (MacFarlane et al., 2003), clay content and CEC (Baran et al., 2014; Nunes et al., 2014). These observed values may be attributed to the clay, organic carbon, $\mathrm{CEC}$ and oxide $\left(\mathrm{Al}_{2} \mathrm{O}_{3}\right.$ and $\left.\mathrm{Fe}_{2} \mathrm{O}_{3}\right)$ contents (Table 1) higher in vertisol than in lixisol and promoted the retention of metals, especially of $\mathrm{Cu}$. These results are in agreement with those of Nunes et al. (2014).

\subsection{Pot Experiments}

\subsubsection{Experimental Design and Soil Treatments}

The experiments were conducted out under controlled conditions in a phytotronic chamber located at Nancy, Interdisciplinary Laboratory of Continental 
Table 1. Physico-chemical properties of the experimental soils. The Newman-Keuls statistical validity test was used for significant differences of each metal content among both experimental soils at the $95 \%$ level of confidence. Significant differences were noted by ${ }^{*} P<0.05$ (significant), ${ }^{* *} P<0.01$ (highly significant), ${ }^{* *} P<0.001$ (very highly significant) and ns (not significant).

\begin{tabular}{|c|c|c|}
\hline Characteristics & Vertisol (VS) & Lixisol (LS) \\
\hline Soil texture & loamy clay & sandy loam \\
\hline Sand (\%) & 25.9 & 68.6 \\
\hline Silt $(\%)$ & 44.8 & 21.6 \\
\hline Clay $(\%)$ & 29.3 & 9.5 \\
\hline Soil pH & 6.1 & 5.8 \\
\hline Organic carbon (OC) (\%) & 0.95 & 0.43 \\
\hline $\mathrm{Al}_{2} \mathrm{O}_{3}$ & 9.8 & 3.5 \\
\hline $\mathrm{Fe}_{2} \mathrm{O}_{3}$ & 4.6 & 1.1 \\
\hline Cation exchange capacity (cmol/kg) & 10.5 & $<1$ \\
\hline \multicolumn{3}{|l|}{ Clay minerals $(\%)$} \\
\hline chlorite & 4 & 0 \\
\hline Illite & 45 & 21 \\
\hline Interstratified Illite/ Chlorite & 4 & 0 \\
\hline kaolinite & 31.5 & 79 \\
\hline smectite + interstratified Illitel smectite & 15.5 & 0 \\
\hline \multicolumn{3}{|l|}{ Metal contents (mg/kg): Total (available) } \\
\hline Cadmium $(C d): n s(n s)$ & $2.80 \pm 0.08(2.53 \pm 0.11)$ & $2.86 \pm 0.12(2.65 \pm 0.01)$ \\
\hline Copper $(\mathrm{Cu}):{ }^{* *}\left({ }^{* *}\right)$ & $136.27 \pm 5.46(5.90 \pm 1.44)$ & $103.78 \pm 3.47(37.11 \pm 0.21)$ \\
\hline Manganese $(M n):{ }^{* * *}(n s)$ & $619.52 \pm 77.44(10.53 \pm 1.16)$ & $154.88 \pm 0.30(14.92 \pm 0.15)$ \\
\hline Lead $(P b): n s(n s)$ & $17.88 \pm 2.51(2.84 \pm 0.05)$ & $12.15 \pm 2.24(2.71 \pm 0.01)$ \\
\hline $\operatorname{Zinc}(Z n):{ }^{* *}(n s)$ & $51.58 \pm 3.82(1.62 \pm 0.10)$ & $28.14 \pm 0.75(1.50 \pm 0.08)$ \\
\hline $\operatorname{Nickel}(N i):^{* *}(n s)$ & $36.71 \pm 2.92(2.23 \pm 0.12)$ & $16.29 \pm 1.18(1.80 \pm 0.01)$ \\
\hline Chromium $(C r):^{* *}(n s)$ & $87.12 \pm 10.42(0.58 \pm 0.03)$ & $45.43 \pm 3.11(0.59 \pm 0.01)$ \\
\hline Mean \pm standard deviation & & \\
\hline
\end{tabular}

Environments, University of Lorraine in France, under the following conditions: $24^{\circ} \mathrm{C} / 16^{\circ} \mathrm{C}$ temperature at day/night, $70 \%$ humidity, $12 \mathrm{~h}$ day, $22.7 \times 10^{3} \mathrm{~cd} \mathrm{~m}^{-2}$ light intensity. Top soil ( $0-20 \mathrm{~cm}$ depth) collected from two experimental stations in the cotton zone of Burkina Faso and experimental soils were air-dried, sieved through $2 \mathrm{~mm}$ mesh and mixed to obtain a homogenous soil sample. The soils samples underwent a preliminary physico-chemical soil assessment (Table 1) prior to the preparation of pot experiment. Vetiver plants were transplanted into plastic pots containing $1 \mathrm{~kg}$ of $2 \mathrm{~mm}$-sieved lixisol or vertisol. Each pot received a single three-month old Vetiver plant with leaves and roots cut at $14 \mathrm{~cm}$ and $5 \mathrm{~cm}$ length, respectively. For both soil types, the unplanted control pots were monitored under the same conditions as the planted pots throughout the 
6-month period of the experiment. The soil moisture content was maintained at $60 \%$ of the field water capacity by adding distilled water every three days. All samples were fertilized by adding a mixture of N/P/K (3/1/1) every 2 weeks (Chen et al., 2004). The study was conducted under the randomized design with three replications. Plants and soils were sampled three (T3) and six months (T6) after Vetiver growth for analyses.

\subsubsection{Heavy Metals Analyses and Statistical}

At 3-month (T3) and 6-month (T6) of experiment, all freshly harvested plants were washed with tap water then rinsed several times with deionized water to remove any adhering soil particles especially at root part. Shoots and roots tissue, previously air-dried for $72 \mathrm{~h}$, were oven-dried at $60^{\circ} \mathrm{C}$ for $48 \mathrm{~h}$. The dry biomass was weighed, ground to a fine powder (Retsch ZM 1) and sieved through a $2-\mathrm{mm}$ mesh. For metal extraction, the microwave digestion method used and $200 \mathrm{mg}$ of plant material was digested using an acid mixture of $69 \% \mathrm{HNO}_{3}$ and $30 \% \mathrm{H}_{2} \mathrm{O}_{2}(2: 1 \mathrm{v} / \mathrm{v})$ into a pressure-resistant PTFE (polytetrafluoroethylene) vessel (Saydut, 2010; Güven \& Akinci, 2011). Metal-concentrations (Cd, Cu, Mn, $\mathrm{Pb}, \mathrm{Zn}, \mathrm{Ni}, \mathrm{Cr}$ ) in plant tissue were analyzed by Inductively Coupled Plasma Atomic Emission Spectroscopy (ICP-AES, Varian 702-ES model) as above with a limit of quantification of $0.63 \mathrm{mg} / \mathrm{kg}$ dry weight.

All experimental data analyzed by performing two-ways analysis of variance (ANOVA), using statistical XLSTAT software, to evaluate the metal accumulation in Vetiver growing under different types of soils. The means of different concentrations were compared by Newman-Keuls's least significant difference tests at the $95 \%$ level of confidence.

\subsubsection{Determination of Phytoremediation Quotient}

The ability of Vetiver grass for metal accumulation and translocation upwards were evaluated by determining the biological accumulation coefficient (BAC), biological concentration factor (BCF) and translocation factor (TF) (Yoon et al., 2006; Ali et al., 2013; Ng et al., 2020), as follows:

$\mathrm{BAC}=$ Concentration of heavy metals in tillers/Concentration of heavy metals in soil;

$\mathrm{BCF}=$ Concentration of heavy metals in roots/Concentration of heavy metals in soil;

$\mathrm{TF}=$ Concentration of heavy metals in shoot/Concentration of heavy metals in roots.

\section{Results and Discussion}

\subsection{Heavy Metal Concentration in Shoots and Roots of Vetiver}

Table 2 shows the concentration of $\mathrm{Cd}, \mathrm{Cu}, \mathrm{Mn}, \mathrm{Pb}, \mathrm{Zn}, \mathrm{Ni}$ and $\mathrm{Cr}$ accumulation in roots and shoots for Vetiver grass. Generaly, Vetiver grass takes up heavy metals in vertisol and lixisol. Metal concentrations in both the roots and shoots did not increased with time (between 3 and 6 months Vetiver growing), but were 
Table 2. Heavy metal concentrations in the roots and shoots of Vetiver (mg/kgdry matter) harvested at T3 and T6 months.

\begin{tabular}{|c|c|c|c|c|c|c|c|}
\hline Samples & $\mathrm{Cd}$ & $\mathrm{Cu}$ & $\mathrm{Mn}$ & $\mathrm{Pb}$ & $\mathrm{Zn}$ & $\mathrm{Ni}$ & $\mathrm{Cr}$ \\
\hline \multicolumn{8}{|c|}{ Shoots (mg/kg DW) } \\
\hline VS_T3 & $1.53 \pm 0.88^{b}$ & $23.15 \pm 12.30^{\mathrm{b}}$ & $103.62 \pm 39.13^{b}$ & $6.08 \pm 6.08^{\mathrm{a}}$ & $23.66 \pm 2.91^{\mathrm{a}}$ & $67.98 \pm 20.33^{\mathrm{a}}$ & $134.45 \pm 10.43^{\mathrm{a}}$ \\
\hline LS-T3 & $22.16 \pm 9.81^{\mathrm{a}}$ & $331.83 \pm 130.94^{\mathrm{a}}$ & $425.78 \pm 110.67^{a}$ & $1.72 \pm 0.62^{\mathrm{a}}$ & $29.25 \pm 9.83^{\mathrm{a}}$ & $65.23 \pm 55.84^{\mathrm{a}}$ & $133.0 \pm 118.18^{\mathrm{a}}$ \\
\hline VS_T6 & $2.25 \pm 0.87^{\mathrm{b}}$ & $44.08 \pm 15.93^{\mathrm{b}}$ & $284.17 \pm 4.02^{\mathrm{ab}}$ & $0.83 \pm 0.07^{\mathrm{a}}$ & $22.83 \pm 10.53^{\mathrm{a}}$ & $126.88 \pm 63.24^{\mathrm{a}}$ & $227.50 \pm 108.9^{a}$ \\
\hline LS-T6 & $21.28 \pm 11.38^{\mathrm{a}}$ & $304.71 \pm 94.38^{\mathrm{a}}$ & $386.67 \pm 129.93^{\mathrm{a}}$ & $0.96 \pm 0.07^{\mathrm{a}}$ & $33.46 \pm 12.20^{\mathrm{a}}$ & $135.04 \pm 53.71^{\mathrm{a}}$ & $245.83 \pm 92.08^{\mathrm{a}}$ \\
\hline \multicolumn{8}{|c|}{ Roots (mg/kg DW) } \\
\hline VS_T3 & $4.55 \pm 1.11^{\mathrm{b}}$ & $145.19 \pm 79.55^{c}$ & $124.19 \pm 116.97^{a}$ & $2.43 \pm 0.46^{\mathrm{a}}$ & $25.50 \pm 4.66^{\mathrm{a}}$ & $5.06 \pm 1.77^{\mathrm{a}}$ & $4.72 \pm 1.75^{\mathrm{a}}$ \\
\hline LS-T3 & $15.82 \pm 2.33^{\mathrm{a}}$ & $709.64 \pm 227.5^{\mathrm{ab}}$ & $178.90 \pm 56.72^{\mathrm{a}}$ & $2.46 \pm 1.19^{\mathrm{a}}$ & $24.87 \pm 5.26^{\mathrm{a}}$ & $3.07 \pm 1.04^{\mathrm{ab}}$ & $3.27 \pm 1.57^{\mathrm{a}}$ \\
\hline VS_T6 & $6.42 \pm 1.31^{\mathrm{b}}$ & $499.17 \pm 72.68^{b}$ & $151.67 \pm 6.41^{\mathrm{a}}$ & $2.29 \pm 0.31^{\mathrm{a}}$ & $24.04 \pm 4.13^{\mathrm{a}}$ & $3.58 \pm 0.75^{\mathrm{ab}}$ & $4.50 \pm 1.15^{\mathrm{a}}$ \\
\hline LS-T6 & $14.88 \pm 4.11^{\mathrm{a}}$ & $637.50 \pm 83.88^{a}$ & $171.67 \pm 36.26^{\mathrm{a}}$ & $3.00 \pm 2.20^{\mathrm{a}}$ & $27.59 \pm 8.58^{\mathrm{a}}$ & $1.84 \pm 0.31^{\mathrm{b}}$ & $2.42 \pm 1.15^{\mathrm{a}}$ \\
\hline
\end{tabular}

Mean \pm standard deviation and for shoots and roots, value in the same column with different superscript are significantly different at $P<0.05$.

depended on the soil type. At 3 months, Vetiver grass tended to accumulate higher concentrations of heavy metals on lixisol. Vetiver growing on lixisol recorded significantly higher $(P<0.05)$ accumulation of $\mathrm{Cd}, \mathrm{Cu}$ and $\mathrm{Mn}$ in both shoots $(22.16,331.83$ and $425.78 \mathrm{mg} / \mathrm{kg}$ ) and roots $(15.82,709.64$ and 178.9 $\mathrm{mg} / \mathrm{kg}$ ) compared to the Vetiver growing on vertisol (Table 2). For $\mathrm{Mn}, \mathrm{Pb}, \mathrm{Zn}$, $\mathrm{Ni}$ and $\mathrm{Cr}$ accumulation in shoot and root parts, not significant difference were found between both experimental soil types. The accumulation especially for $\mathrm{Cd}$, $\mathrm{Cu}$ and $\mathrm{Mn}$ were significantly greater for lixisol than vertisol in relation to the negligible lixisol CEC compared to the vertisol CEC (Table 1). The highest organic carbon content increases the CEC of the vertisol which retains metallic elements and reduces significantly the heavy metals bioavailability. These findings are in agreement with Ondo Zue Abaga et al. (2014b) study that reported that $\mathrm{Cu}$ and $\mathrm{Cd}$ adsorption were significantly higher in vertisol compared to lixisol. However, at 3 an 6 months, accumulate concentrations of Ni and $\mathrm{Cr}$ were higher in shoots than in roots of Vetiver grass in both vertisol and lixisol (Table 2). In root part, higher $\mathrm{Ni}$ and $\mathrm{Cr}$ accumulation was found in vetiver growing on vertisol compared on lixisol. This result may be attributed to the total initial $\mathrm{Ni}$ and $\mathrm{Cr}$ concentrations significanty higher in vertisol than lixisol (Table 1). The findings were in line with previous studies that amount of metals uptake by plant root increased as initial concentration of heavy metals increased (Roongtanakiat \& Chairoj, 2001; Ghosh \& Singh, 2005). This suggests that Vetiver grass can be considered like a rhizofiltrator for $\mathrm{Ni}$ and $\mathrm{Cr}$ due to higher absorption of most heavy metals by root at different metal concentrations (Truong, 2000).

For both types of soil, time did not seem to have a significant impact in metals concentrations stored in Vetiver shoots and roots (Table 2). Heavy metal adsorption and their accumulation in Vetiver grass were important following a growth period of three months. Whereas, the accumulation was lower for a 
growth period ranging from 3 to 6 month, probably due to the weak concentrations of initial metal-bioavailable in soils. This could be related to our experimental conditions such as soil weight ( $1 \mathrm{~kg}$ per pot) combined with the experiment duration (6 months) which may constitute limiting factors in this study. Generally, phytoremediation studies of heavy metal contaminated soils using Vetiver grass are often carried out with at least $2 \mathrm{~kg}$ of soil per pot and the experiment duration between 2 and 3 moths (Jampasri \& Saeng-Ngam, 2019; Ng et al., 2020), and Vetiver growth is often by nutrients, EDTA to promote metal uptake and accumulation in plant tissues (Aksorn \& Chitsomboon, 2013; Ng et al., 2016). Under these experimental conditions, plant growth is fast, its root density becomes more important and increase surface area for metal absorption by plant roots (Suelee et al., 2017).

Although the metal absorption by Vetiver grass is shown in the both studied soils, the highest concentrations were found in plant tissues grown on lixisol for T3 and T6, in the following order $\mathrm{Cu}>\mathrm{Mn}>\mathrm{Zn}>\mathrm{Cd}>\mathrm{Cr}>\mathrm{Ni}>\mathrm{Pb}$ in roots and $\mathrm{Mn}>\mathrm{Cu}>\mathrm{Cr}>\mathrm{Ni}>\mathrm{Zn}>\mathrm{Cd}>\mathrm{Pb}$ in shoots (Table 2). The observed variation in the amount of metals accumulated by Vetiver in their various parts in the various soils is an indication that metal uptake by Vetiver is primarily dependent on the soil quality and metal concentrations in their habitual soil environment (Chunilall et al., 2005). Indeed, metal adsorption in soil increases with high soil properties such as organic carbon, clay minerals content, $\mathrm{Al}_{2} \mathrm{O}_{3}, \mathrm{Fe}_{2} \mathrm{O}_{3}$ and CEC (Covelo et al., 2007; Cerqueira et al., 2011) higher in vertisol compared to lixisol (Table 1) reducing their bioavailability. This would explain the lower metal content accumulated in vetiver generally harvested in vertisol. Thus, Vetiver is shown to be more effective for lixisol remediation.

\subsection{Translocation and Bioaccumulation Factors}

The association of the different heavy metals accumulated from the tropical soils into the roots and shoots for Vetiver grass, in terms of BAC, BCF and TF are summarized in Table 3. A critical value greater than one $(>1)$ for plants' BAC, $\mathrm{BCF}$ and TF is used to evaluate the potentials of plant species for phytoremediation method such as stabilization and extraction processes (Yoon et al., 2006; Cui et al., 2007; Li et al., 2007). The results showed that Vetiver had BAC > 1 at three months for $\mathrm{Cu}, \mathrm{Mn}$ and $\mathrm{Cr}$ mainly in lixisol (LS), and at six months for $\mathrm{Cd}$, $\mathrm{Cu}, \mathrm{Mn}, \mathrm{Zn}, \mathrm{Ni}$ and $\mathrm{Cr}$ in both soil types, with the higher values in the lixisol $14.9,9.5,1,1.5,5.9$ and 2, respectively. These results indicate that Vetiver grass can be used for $\mathrm{Cd}, \mathrm{Cu}, \mathrm{Mn}, \mathrm{Zn}, \mathrm{Ni}$ and $\mathrm{Cr}$ phytoremediation, especially in the lixisol. Plants with well-developed cellular mechanisms for heavy metal detoxification and tolerance $(\mathrm{BAC}>1)$ are used as an indicator of high heavy metals accumulator plant species (Ghosh \& Singh, 2005).

A good phytoremediator species possesses BCF value of greater than 1 (Zhang et al., 2002). Noticeably, after six months growing, the BCF values were greater than 1 for $\mathrm{Cd}$ and $\mathrm{Cu}$ in the both soils and for $\mathrm{Zn}$ in lixisol. The observed values indicate a great absorption of $\mathrm{Cd}, \mathrm{Cu}$ and $\mathrm{Zn}$ in the lixisol, with the higher $\mathrm{BCF}$ 
Table 3. Biological Accumulation Coefficient (BAC), Biological Coefficient Factor (BCF) and Translocation Factor (TF) of Vetiver grass sampled after 3 months (T3) and 6 months (T6) growing in the vertisol (VS) and lixisol (LS).

\begin{tabular}{|c|c|c|c|c|c|c|c|}
\hline \multirow{2}{*}{ Metal } & \multirow{2}{*}{ Soil type } & \multicolumn{2}{|c|}{ BAC } & \multicolumn{2}{|c|}{ BCF } & \multicolumn{2}{|c|}{$\mathrm{TF}$} \\
\hline & & T3 & T6 & $\mathrm{T} 3$ & T6 & T3 & T6 \\
\hline \multirow[t]{2}{*}{$\mathrm{Cd}$} & VS & nd & $2.0 \pm 0.3$ & nd & $3.4 \pm 0.9$ & $0.3 \pm 0.1$ & $0.4 \pm 0.2$ \\
\hline & LS & nd & $14.9 \pm 6.8$ & nd & $11.8 \pm 4.7$ & $1.4 \pm 0.7$ & $1.4 \pm 0.5$ \\
\hline \multirow[t]{2}{*}{$\mathrm{Cu}$} & VS & $0.6 \pm 0.3$ & $3.5 \pm 0.8$ & $1.2 \pm 0.7$ & $8.1 \pm 1.8$ & $0.2 \pm 0.1$ & $0.1 \pm 0.0$ \\
\hline & LS & $6.1 \pm 1.8$ & $9.5 \pm 2.1$ & $9.6 \pm 3.7$ & $14.5 \pm 3.1$ & $0.5 \pm 0.3$ & $0.5 \pm 0.1$ \\
\hline \multirow[t]{2}{*}{$\mathrm{Mn}$} & VS & $0.1 \pm 0.0$ & $0.2 \pm 0.0$ & $0.2 \pm 0.1$ & $0.1 \pm 0.0$ & $1.2 \pm 0.6$ & $1.9 \pm 0.1$ \\
\hline & LS & $2.2 \pm 0.6$ & $1.0 \pm 0.3$ & $1.2 \pm 0.4$ & $0.6 \pm 0.1$ & $2.4 \pm 0.2$ & $2.4 \pm 1.3$ \\
\hline \multirow[t]{2}{*}{$\mathrm{Pb}$} & VS & nd & $0.0 \pm 0.0$ & nd & $0.1 \pm 0.1$ & $0.6 \pm 1.1$ & $0.1 \pm 0.2$ \\
\hline & LS & nd & $0.1 \pm 0.1$ & nd & $0.2 \pm 0.3$ & $0.2 \pm 0.4$ & $0.0 \pm 0.1$ \\
\hline \multirow[t]{2}{*}{$\mathrm{Zn}$} & VS & nd & $0.4 \pm 0.2$ & nd & $0.5 \pm 0.2$ & $1.0 \pm 0.3$ & $1.0 \pm 0.6$ \\
\hline & LS & nd & $1.5 \pm 0.8$ & nd & $1.4 \pm 0.7$ & $1.2 \pm 0.3$ & $1.3 \pm 0.5$ \\
\hline \multirow[t]{2}{*}{$\mathrm{Ni}$} & VS & nd & $2.2 \pm 0.9$ & nd & $0.1 \pm 0.1$ & $15.8 \pm 10.1$ & $34.5 \pm 11.3$ \\
\hline & LS & nd & $5.9 \pm 2.7$ & nd & $0.1 \pm 0.0$ & $23.4 \pm 21.6$ & $75.5 \pm 31.3$ \\
\hline \multirow[t]{2}{*}{$\mathrm{Cr}$} & VS & $1.1 \pm 0.5$ & $1.33 \pm 0.7$ & $0.1 \pm 0.0$ & $0.0 \pm 0.0$ & $34.9 \pm 25.9$ & $50.7 \pm 18.3$ \\
\hline & LS & nd & $2.0 \pm 0.9$ & nd & $0.0 \pm 0.0$ & $45.5 \pm 38.6$ & $121.5 \pm 70.7$ \\
\hline
\end{tabular}

values of 11.8, 14.5 and 1.4, respectively (Table 3), exhibiting firstly that the $\mathrm{Cu}$ accumulation was higher than the $\mathrm{Cd}, \mathrm{Zn}$ and secondly that the metal accumulation potential of Vetiver was higher in the lixisol than in the vertisol. These heavy metals showed a preferential accumulation in the roots of Vetiver after their absorption from soils. In case of soil weight is more than $1 \mathrm{~kg}$ (case of our study), the more important root density of Vetiver would be more efficiency for metal accumulation due to increased surface area for metal absorption by plant roots (Suelee et al., 2017). Elevated concentrations of heavy metals in roots of plants species and low translocation into above ground parts (BCF) indicate their suitability for phytostabilization (Ghosh \& Singh, 2005).

Translocation factor (TF) is the ratio that indicates the relative transportation of metals from roots to shoots of the plants (Mellem et al., 2012). TF values $>1$ indicate the greater translocation of metals from root to the shoot part of the plant. In contrast, TF values $<1$ mean that metals are largely store in the root part of plants (Mellem et al., 2012). High root to shoot translocation (TF > 1) as observed for $\mathrm{Cd}$ in the lixisol and for $\mathrm{Mn}, \mathrm{Zn}, \mathrm{Ni}$ and $\mathrm{Cr}$ in the both studied soils. These results showed the ability of Vetiver to translocate heavy metals to easily harvestable parts (shoots). Similar TF values were obtained at three and six months for $\mathrm{Cd}, \mathrm{Mn}$ and $\mathrm{Zn}$ in the lixisol (1.4, 2.4 and 1.2) and in vertisol (0.3, 1.2 and 1.0), respectively (Table 3). Generally, metals such as $\mathrm{Cd}, \mathrm{Pb}$ and $\mathrm{Cu}$ preferentially accumulate in roots and often show low TF values (Aksorn \& Chitsomboon, 2013; Jampasri \& Saeng-Ngam, 2019). However, in comparison with Ng et al. (2016), our study shows low metal translocation. This observation can 
be explained by the application of soil amendments EDTA, elemental S and $\mathrm{N}$-fertilizer significantly increasing metal accumulation in the shoots in plant, with metal TF generally > 1.72 (Rahman et al., 2013; Ng et al., 2016).

Cadmium (Cd), $\mathrm{Mn}$ and $\mathrm{Zn}$ translocation decrease after three months growing of Vetiver. These TF values are lower compared to those of $\mathrm{Ni}$ (15.8 to 75.5) and $\mathrm{Cr}$ (34.9 to 121.5), with the highest TF being obtained in lixisol following a 6-month growth period. This result is an indication that Vetiver grass has vital characteristics to be used in phytoextraction (Malik et al., 2010). The observed high $\mathrm{Ni}$ and $\mathrm{Cr}$ translocation quotient may be attributed to well-developed metal detoxification mechanism based on sequestration in the tolerant plant species (Ghosh \& Singh, 2005; Cui et al., 2007).

According to Yoon et al. (2006), a plant is considered as a hyperaccumulator of ETM when his translocation factor (TF) is greater than 1. Based on that definition, Vetiver can be considered as a hyperaccumulator of $\mathrm{Cd}$ in lixisol and $\mathrm{Mn}$, $\mathrm{Zn}, \mathrm{Ni}$ and $\mathrm{Cr}$ in both soil types, with a more important hyperaccumulation in lixisol. However, according to Baker \& Brooks (1989), a plant is said to be a hyperaccumulator if it is capaple of storing in its aerial parts more than 100 $\mathrm{mg} / \mathrm{kgdry}$ plant of $\mathrm{Cd}$ and $\mathrm{As}, 1000 \mathrm{mg} / \mathrm{kg}$ of $\mathrm{Co}, \mathrm{Cu}, \mathrm{Cr}$ and $\mathrm{Pb}$, and 10000 $\mathrm{mg} / \mathrm{kg}$ of Mn, Zn et Ni (Watanabe, 1997; Baker \& Brooks, 1989). According to our results, none of the heavy metals accumulated in Vetiver shoots exceeds those limits. This finding could be explained by weak ETM concentrations in the soil sampled.

Despite the low accumulation of heavy metal found in the root and shoot, the observed values of BAC, BCF and FT showed that Vetiver exhibited varying levels of phytoaccumulation potentials. Results from the present study suggested that Vetiver grass could effectively act as phytostabilizer for Cd in vertisol and $\mathrm{Cu}$ in lixisol and vertisol with BCF values greater than 1 and TF values of less than 1. However, despite the experimental duration, Vetiver is more favorable for phytoextraction of $\mathrm{Cd}$ in lixisol and $\mathrm{Mn}, \mathrm{Zn}, \mathrm{Ni}$ and $\mathrm{Cr}$ in the both vertisol and lixisol due to $\mathrm{TF}>1$.

\section{Conclusion}

Vetiver grass (Vetiveria zizanioides) was found effective in heavy metals (Cd, $\mathrm{Cu}, \mathrm{Mn}, \mathrm{Pb}, \mathrm{Zn}, \mathrm{Ni}, \mathrm{Cr}$ ) accumulation in both studied tropical soils, but the rate of metal accumulation depends on the soil nature. Vetiver grass is a better accumulator of heavy metals in lixisol than vertisol at T3 and T6, in the order of $\mathrm{Cu}>\mathrm{Mn}>\mathrm{Zn}>\mathrm{Cd}>\mathrm{Cr}>\mathrm{Ni}>\mathrm{Pb}$ in roots and $\mathrm{Mn}>\mathrm{Cu}>\mathrm{Cr}>\mathrm{Ni}>\mathrm{Zn}>\mathrm{Cd}>$ $\mathrm{Pb}$ in shoots, due to soil physic-chemical properties limiting the metal bioavailability in vertisol. In terms of different plant parts, at T3 and T6 plant growing, the shoots exhibited a strong tendency for greater uptake and accumulation of all heavy metals, except $\mathrm{Cu}$ and $\mathrm{Pb}$ with higher accumulation in roots than shoots. Vetiver grass may be considered as a promising $\mathrm{Cd}, \mathrm{Cu}$ and $\mathrm{Zn}$ phyto-stabilizer due to its high BCF values of $>1$ in both soils. However, Vetiver is 
more favorable for phytoextraction of $\mathrm{Cd}$ in lixisol and $\mathrm{Mn}, \mathrm{Zn}, \mathrm{Ni}$ and $\mathrm{Cr}$ in vertisol due to high TF values $>1$. Our study demonstrated that Vetiver grass can be considered as a suitable candidate for the remediation of both tropical soils contaminated with heavy metal under laboratory test conditions. Future research may need to investigate metal uptake mechanisms, accumulation and tolerance of Vetiver grass in natural conditions on agricultural soils in Burkina Faso in order to have additional data on the growth of Vetiver and its up-take metals capacity according to climatic seasons in this country.

\section{Acknowledgements}

This work was financially supported in part by a CORUS II Project and a Gabonese Government Fellowship. The authors thank the Botanical Garden of Montet (Villers-les-Nancy, 54 France) for material support and for providing the Vetiver plants. We also thank Paul SAVADOGO (INERA, Ouagadougou, Burkina-Faso) for providing the studied soils and Regine MOSSER-RUCK (GeoRessources, Nancy 54 France) for the clay mineralogical compositions.

\section{The Author's Contributions}

All authors contributed to the research design, analysis data, and the manuscript's writing.

\section{Conflicts of Interest}

The authors declare no conflicts of interest regarding the publication of this paper.

\section{References}

Aksorn, E., \& Chitsomboon, B. (2013). Bioaccumulation of Heavy Metal Uptake by Two Different Vetiver Grass (Vetiveria zizanioides and Vetiveria nemoralis) Species. African Journal of Agricultural Research, 8, 3166-3171.

Ali, H., \& Khan, E. (2017). Environmental Chemistry in the Twenty-First Century. Environmental Chemistry Letters, 15, 329-346. https://doi.org/10.1007/s10311-016-0601-3

Ali, H., Khan, E., \& Ilahi, I. (2019). Environmental Chemistry and Ecotoxicology of Hazardous Heavy Metals: Environmental Persistence, Toxicity, and Bioaccumulation. Journal of Chemistry, 2019, Article ID: 6730305. https://doi.org/10.1155/2019/6730305

Ali, H., Khan, E., \& Sajad, M. A. (2013). Phytoremediation of Heavy Metals-Concepts and Applications. Chemosphere, 91, 869-881. https://doi.org/10.1016/j.chemosphere.2013.01.075

Ali, H., \& Khan, E. (2018). What Are Heavy Metals? Long-Standing Controversy over the Scientific Use of the Term "Heavy Metals": Proposal of a Comprehensive Definition. Toxicological \& Environmental Chemistry, 100, 6-19. https://doi.org/10.1080/02772248.2017.1413652

Antiochia, R., Luigi, C., \& Paola, G. K. M. (2007). The Use of Vetiver for Remediation of Heavy Metal Soil Contamination. Analytical and Bioanalytical Chemistry, 388, 947-956. https://doi.org/10.1007/s00216-007-1268-1 
Azam, M. M. (2016). Soil Contamination and Remediation Measures: Revisiting the Relevant Laws and Institutions. In Environmental Remediation Technologies for Metal-Contaminated Soils (pp. 99-124). Springer. https://link.springer.com/chapter/10.1007/978-4-431-55759-3 5 https://doi.org/10.1007/978-4-431-55759-3 5

Baker, A. J. M., \& Brooks, R. R. (1989). Terrestrial Higher Plants Which Hyperaccumulate Metallic Elements. A Review of Their Distribution, Ecology and Phytochemistry. Biorecovery, 1, 81-126.

Barakat, M. A. (2011). New Trends in Removing Heavy Metals from Industrial Wastewater. Arabian Journal of Chemistry, 4, 361-377. https://doi.org/10.1016/j.arabjc.2010.07.019

Baran, A., Czech, T., \& Wieczorek, J. (2014). Chemical Properties and Toxicity of Soils Contaminated by Mining Activity. Ecotoxicology, 23, 1234-1244. https://doi.org/10.1007/s10646-014-1266-y

Bradl, H. B. (2005). Heavy Metals in the Environment. In H. B. Bradl (Ed.), Sources and Origins of Heavy Metals (pp. 1-27). Elsevier Academic Press. https://doi.org/10.1016/S1573-4285(05)80020-1

Cerqueira, B., Covelo, E. F., Andrade, L., \& Vega, F. A. (2011). The Influence of Soil Properties on the Individual and Competitive Sorption and Desorption of $\mathrm{Cu}$ and $\mathrm{Cd}$. Geoderma, 162, 20-26. https://doi.org/10.1016/j.geoderma.2010.08.013

Chen, Y., Shen, Z., \& Li, X. (2004). The Use of Vetiver Grass (Vetiveria zizanioides) in the Phytoremediation of Soils Contaminated with Heavy Metals. Applied Geochemistry, 19, 1553-1565. https://doi.org/10.1016/j.apgeochem.2004.02.003

Chunilall, V., Kindness, A., \& Johnalagada, S. B. (2005). Heavy Metal Uptake by Two Edible Amaranthus Herbs Grown on Soils Contaminated with Lead, Mercury, Cadmium, and Nickel. Journal of Environmental Science and Health, 40, 375-385. https://doi.org/10.1081/PFC-200045573

Clemens, S., \& Ma, J. F. (2016). Toxic Heavy Metal and Metalloid Accumulation in Crop Plants and Foods. Annual Review of Plant Biology, 67, 489-512. https://doi.org/10.1146/annurev-arplant-043015-112301

Covelo, E. F., Vega, F. A., \& Andrade, M. L. (2007). Simultaneous Sorption and Desorption of $\mathrm{Cd}, \mathrm{Cr}, \mathrm{Cu}, \mathrm{Ni}, \mathrm{Pb}$, and $\mathrm{Zn}$ in Acid Soils I. Selectivity Sequences. Journal of Hazardous Materials, 147, 852-861. https://doi.org/10.1016/j.jhazmat.2007.01.123

Cui, S., Zhou, Q., \& Chao, L. (2007). Potential Hyper-Accumulation of Pb, Zn, Cu and Cd in Endurant Plants Distributed in an Old Semetery, Northeast, China. Environmental Geology, 51, 1043-1045. https://doi.org/10.1007/s00254-006-0373-3

Danh, L. T., Truong, P., Mammucari, R., Tran, T., \& Foster, N. (2009). Vetiver Grass, Vetiveria zizanioides. a Choice Plant for Phytoremediation of Heavy Metals and Organic Wastes. International Journal of Phytoremediation, 11, 664-691. https://doi.org/10.1080/15226510902787302

Darajeh, N., Truong, P., Rezania, S., Alizadeh, H., \& Leung, D. W. (2019). Effectiveness of Vetiver Grass versus Other Plants for Phytoremediation of Contaminated Water. Journal of Environmental Treatment Techniques, 7, 485-500.

Doran, J. W. (2002). Soil Health and Global Sustainability: Translating Science into Practice. Agriculture, Ecosystems \& Environment, 88, 119-127. https://doi.org/10.1016/S0167-8809(01)00246-8

Garbisu, C., \& Alkorta, I. (2003). Basic Concepts on Heavy Metal Soil Bioremediation. European Journal of Mineral Processing and Environmental Protection, 3, 58-66. 
Ghosh, M., \& Singh, S. P. (2005). A Review of Phytoremediation of Heavy Metals and Utilization of It's By-Products. Applied Ecology and Environmental Research, 3, 1-18. https://doi.org/10.15666/aeer/0301 001018

Glass, D. J. (2000). Economic Potential of Phytoremediation. In I. Raskin, \& B. D. Ensley (Eds.), Phytoremediation of Toxic Metals: Using Plants to Clean Up the Environment (pp. 15-31). John Wiley.

Gnansounou, E., Alves, C. M., \& Raman, J. K. (2017). Multiple Applications of Vetiver Grass-A Review. International Journal of Environmental Sciences, 2, 125-141.

Gomes, H. I. (2012). Phytoremediation for Bioenergy: Challenges and Opportunities. Environmental Technology Reviews, 1, 59-66. https://doi.org/10.1080/09593330.2012.696715

Gómez-Sagasti, M. T., Epelde, L., Alkorta, I., \& Garbisu, C. (2016). Reflections on Soil Contamination Research from a Biologists Point of View. Applied Soil Ecology, 105, 207-210. https://doi.org/10.1016/j.apsoil.2016.04.004

Güven, D. E., \& Akinci, G. (2011). Comparison of Acid Digestion Techniques to Determine Heavy Metals in Sediment and Soil Samples. Gazi University Journal of Science, 24, 29-34.

IUSS Working Group WRB (2006). World Reference Base for Soil Resources 2006. World Soils Resources Reports No. 103, FAO.

Jamagne, M. (1967). Bases et techniques d'une cartographie des sols. Annales Agronomiques, 18, 1-142.

Jampasri, K., \& Saeng-Ngam, S. (2019). Phytoremediation and Accumulation of Cadmium from Contaminated Saline Soils by Vetiver Grass. Environmental Control in Biology, 57, 61-67. https://doi.org/10.2525/ecb.57.61

Khan, T., Muhammad, S., Khan, B., \& Khan, H. (2011). Investigating the Levels of Selected Heavy Metals in Surface Water of Shah Alam River (A Tributary of River Kabul, Khyber Pakhtunkhwa). Journal of Himalayan Earth Sciences, 44, 71-79.

Khan, A. G. (2005). Role of Soil Microbes in the Rhizospheres of Plants Growing on Trace Metal Contaminated Soils in Phytoremediation. Journal of Trace Elements in Medicine and Biology, 18, 355-364. https://doi.org/10.1016/j.jtemb.2005.02.006

Li, M. S., Luo, Y. P., \& Su, Z. Y. (2007). Heavy Metals Concentrations in Soils and Plant Accumulation in a Restored Manganese Mine Land in Guangxi, South China. Environmental Pollution, 147, 168-175. https://doi.org/10.1016/j.envpol.2006.08.006

Lombi, E., Zhao, F. J., Dunham, S. J., \& McGrath, S. P. (2001). Phytoremediation of Heavy Metal-Contaminated Soils. Journal of Environmental Quality, 30, 1919-1926. https://doi.org/10.2134/jeq2001.1919

MacFarlane, G. R., Pulkownik, A., \& Burchett, M. D. (2003). Accumulation and Distribution of Heavy Metals in the Grey Mangrove, Avicennia marina (Forsk.) Vierh: Biological indication Potential. Environmental Pollution, 123, 139-151. https://doi.org/10.1016/S0269-7491(02)00342-1

Maffei, M. (2002). Introduction to the Genus Vetiveria. In M. Maffei (Ed.), Vetiveria. The Genus Vetiveria (pp. 1-18). Taylor and Francis Publishers. https://doi.org/10.1201/9780203218730

Mahar, A., Wang, P., Ali, A., Awasthi, M. K., Lahori, A. H., Wang, Q., Li, R., \& Zhang, Z. (2016). Challenges and Opportunities in the Phytoremediation of Heavy Metals Contaminated Soils: A Review. Ecotoxicology Environmental Safety, 126, 111-121. https://doi.org/10.1016/j.ecoenv.2015.12.023

Malik, R. N., Husain, S. Z., \& Nazir, I. (2010). Heavy Metal Contamination and Accumu- 
lation in Soil and Wild Plant Species from Industrial Area of Islamabad, Pakistan. Pakistan Journal Botany, 42, 291-301.

Martin, S., \& Griswold, W. (2009). Human Health Effects of Heavy Metals. Environmental Science and Technology Briefs Citizens, 15, 1-6.

McKinney, J., \& Rogers, J. (1992). Metal Bioavailability. Environmental Science and Technology, 26, 1298-1299. https://doi.org/10.1021/es00031a603

Meers, E., Samson, R., Tack, F. M. G., Ruttens, A., Vandegehuchte, M., Vangronsveld, J., \& Verloo, M. G. (2007). Phytoavailability Assessment of Heavy Metals in Soils by Single Extractions and Accumulation by Phaseolus vulgaris. Environmental and Experimental Bototany, 60, 385-396. https://doi.org/10.1016/j.envexpbot.2006.12.010

Mellem, J. J., Baijnath, H., \& Odhav, B. (2012). Bioaccumulation of Cr, Hg, As, Pb, Cu and $\mathrm{Ni}$ with the Ability for Hyperaccumuation by Amaranthus dubius. African Journal of Agricultural Research, 7, 591-596. https://doi.org/10.5897/AJAR11.1486

Mosser-Ruck, R., \& Cathelineau, M. (2004). Experimental Transformation of Na, Ca-Smectite under Basic Conditions at $150^{\circ}$ C. Applied Clay Science, 26, 259-273.

https://doi.org/10.1016/j.clay.2003.12.011

Neisi, A., Vosoughi, M., Mohammadi, M. J., Ohammadi, B., \& Naeimabadi, A. (2014). Phytoremediation of by Helianthus Plant. Journal of Torbat Heydariyeh University of Medical Sciences, 2, 55-65.

Ng, C. C., Boyce, A. N., Abas, M. R., Mahmood, N. Z., \& Han, F. (2019). Phytoassessment of Vetiver Grass Enhanced with EDTA Soil Amendment Grown in Single and Mixed Heavy Metal-Contaminated Soil. Environmental Monitoring and Assessment, 191, 1-16. https://doi.org/10.1007/s10661-019-7573-2

Ng, C. C., Boyce, A. N., Abas, M. R., Mahmood, N. Z., \& Han, F. (2020). Evaluation of Vetiver Grass Uptake Efficiency in Single and Mixed Heavy Metal Contaminated Soil. Environmental Processes, 7, 207-226. https://doi.org/10.1007/s40710-019-00418-2

Ng, C. C., Boyce, A. N., Rahman, M. M., \& Abas, M. R. (2016). Effects of Different Soil Amendments on Mixed Heavy Metals Contamination in Vetiver Grass. Bulletin of Environmental Contamination and Toxicology, 97, 695-701.

https://doi.org/10.1007/s00128-016-1921-5

Nunes, J. R., Ramos-Miras, J., Lopez-Piñeiro, A., Loures, L., Gil, C., Coelho, J., \& Loures, A. (2014). Concentrations of Available Heavy Metals in Mediterranean Agricultural soils and Their Relation with Some Soil Selected Properties: A Case Study in Typical Mediterranean Soils. Sustainability, 6, 9124-9138. https://doi.org/10.3390/su6129124

Ondo Zue Abaga, N., Dousset, S., Mbengue, S., \& Munier-Lamy, C. (2014b). Is Vetiver Grass of Interest for the Remediation of $\mathrm{Cu}$ and $\mathrm{Cd}$ to Protect Marketing Gardens in Burkina-Faso? Chemosphere, 113, 42-47.

https://doi.org/10.1016/j.chemosphere.2014.04.010

Ondo Zue Abaga, N., Dousset, S., Munier-Lamy, C., \& Billet, D. (2014a). Effectiveness of Vetiver Grass (Vetiveria zizanioides L. Nash) for Phytoremediation of Endosulfan in Two Cotton Soils from Burkina Faso. International Journal of Phytoremediation, 16, 95-108. https://doi.org/10.1080/15226514.2012.759531

Pilbeam, D. J., \& Barker, A. V. (2007). Handbook of Plant Nutrition. CRC Press.

Rahman, M. A., Reichman, S. M., Luigi De Filippis, Sany, S. B. T., \& Hasegawa, H. (2016). Phytoremediation of Toxic Metals in Soils and Wetlands: Concepts and Applications. In H. Hasegawa, I. Md. M. Rahman, \& M. A. Rahman (Eds.), Environmental Remediation Technologies for Metal-Contaminated Soils (pp. 161-195). Springer Japan KK. https://doi.org/10.1007/978-4-431-55759-3 8 
Rahman, M. M., Azirun, S. M., \& Boyce, A. N. (2013). Enhanced Accumulation of Copper and Lead in Amaranth (Amaranthus paniculatus), Indian Mustard (Brassica juncea) and Sunflower (Helianthus annuus). PLoS ONE, 8, e62941. https://doi.org/10.1371/journal.pone.0062941

Roongtanakiat, N., \& Chairoj, P. (2001). Uptake Potential of Some Heavy Metals by Vetiver Grass. Kasersart Journal: Natural Science, 3, 46-50.

Saydut, A. (2010). Microwave Acid Digestion for the Determination of Metals in Subbitumnious Coal Bottom Ash by ICP-OES. Energy Exploration \& Exploitation, 28, 105-115. http://www.jstor.org/stable/26160896 https://doi.org/10.1260/0144-5987.28.2.105

Schlüter, T. (2008). Geological Atlas of Africa: With Notes on Stratigraphy, Tectonics, Economic Geology, Geohazards, Geosites and Geoscientific Education of Each Country (2nd ed., p. 50). Springer-Verlag.

Singh, S., Melo, J. S., Eapen, S., \& D’Souza, S. F. (2008). Potential of Vetiver (Vetiveria zizanoides L. Nash) for Phytoremediation of Phenol. Ecotoxicology and Environmental Safety, 71, 671-676. https://doi.org/10.1016/j.ecoenv.2007.10.023

Storelli, M. M. (2008). Potential Human Health Risks from Metals ( $\mathrm{Hg}$, Cd, and $\mathrm{Pb}$ ) and Polychlorinated Biphenyls (PCBs) via Seafood Consumption: Estimation of Target Hazard Quotients (THQs) and Toxic Equivalents (TEQs). Food and Chemical Toxicology, 46, 2782-2788. https://doi.org/10.1016/j.fct.2008.05.011

Suelee, A. L., Hasan, S. N. M. S., Kusin, F. M., Yusuff, F. M., \& Ibrahim, Z. Z. (2017). Phytoremediation Potential of Vetiver Grass (Vetiveria zizanioides) for Treatment of Metal-Contaminated Water. Water, Air, \& Soil Pollution, 228, 158. https://doi.org/10.1007/s11270-017-3349-x

Truong, P., \& Danh, L. T. (2015). The Vetiver System for Improving Water Quality: Prevention and Treatment of Contaminated Water and Land (2nd ed.). The Vetiver Network International. https://www.vetiver.org/TVN Water quality\%202\%20ed.pdf

Truong, P. N. V. (2000). The Global Impact of Vetiver Grass Technology on the Environment. In Proceedings of the Second International Vetiver Conference PRVN/ORDPB (pp. 48-61).

UNDP (2021). Climate Change Adaptation: Burkina Faso. https://www.adaptation-undp.org/explore/western-africa/burkina-faso

USAID (United States Agency of International Development) (2017). Burkina Faso.

Watanabe, M. E. (1997). Phytoremediation on the Brink of Commercialization. Environmental Sciences and Technology, 31, 182-186. https://doi.org/10.1021/es972219s

Yoon, J., Cao, X., Zhou, Q., \& Ma, L. K. (2006). Accumulation of Pb, Cu, and Zn in Native Plants Growing on a Contaminated Florida Site. Science of the Total Environment, 368, 456-464. https://doi.org/10.1016/j.scitotenv.2006.01.016

Zhang, W., Cai, Y., Tu, C., \& Ma, L. Q. (2002). Arsenic Speciation and Distribution in an Arsenic Hyperaccumulating Plant. Science of Total Environment, 300, 167-177. https://doi.org/10.1016/S0048-9697(02)00165-1 